\title{
TELAAH BUKU TEKS TEMATIK TERPADU KELAS IV SD KURIKULUM 2013
}

\author{
Yeni Ernawati \\ Dosen Universitas Bina Darma \\ Jalan Jenderal Ahmad Yani, No.03, Palembang \\ Su-rel: yeni.ernawati@binadarma.ac.id.
}

Article info

Article history:

Received: 05/11/2018

Revised : 06/11/2018

Accepted: 15/12/2018

\begin{abstract}
A B S T R A C T
Textbooks are learning resources that are used as guidelines or handles in learning activities by students and educators (teachers). As a guide and learning material in learning activities in schools, textbooks must conform the standards of feasibility. Standards for the feasibility of textbooks as learning material, including the feasibility of content, language, and presentation. The results "Tematik Terpadu Kelas IV SD Kurikulum 2013”, namely: a) Feasibility of content: this book is appropriate and in accordance with the curriculum, KI and KD already implied in the textbook material;b) Feasibility of language: this book is feasible by using simple, communicative, and in accordance with the rules of Indonesian language that are good and correct; c) Feasibility of presentation: the presentation of this book is feasible, coherent, and interesting. Material is presented in a coherent manner, from easy to difficult, concrete to abstract. In addition, because this book is used in fourth grade,
\end{abstract}

Keywords:

Study of Textbooks,

Tematik, , Curriculum

Buku teks adalah sumber belajar yang digunakan sebagai pedoman atau pegangan dalam kegiatan pembelajaran oleh peserta didik dan pendidik (guru). Sebagai pedoman dan bahan belajar dalam kegiatan pembelajaran di sekolah, buku teks harus memenuhi standar kelayakan. Standar kelayakan buku teks sebagai bahan belajar, meliputi kelayakan isi, bahasa, dan penyajian. Hasil telaah buku teks Tematik Terpadu Kelas IV SD Kurikulum 2013, yaitu: a) Kelayakan isi: buku ini sudah layak dan sesuai dengan kurikulum, KI dan KD sudah tersirat dalam materi buku teks; b)Kelayakan bahasa: buku ini sudah layak dengan menggunakan bahasa yang lugas, komunikatif, serta sesuai dengan kaidah Bahasa Indonesia yang baik danbenar; c) Kelayakan penyajian: penyajian buku ini suda hlayak, runtut, dan menarik. Materi disajikan secara runtut, dari mudah kesukar, konkret ke abstrak.
Direktorat Riset dan Pengabdian Masyarakat Universitas Bina Darma 


\section{PENDAHULUAN}

Buku memiliki peranan penting dalam pengembangan ilmu pengetahuan. Buku merupakan salah satu sumber bahan ajar. Ilmu pengetahuan, informasi, danhiburan dapat diperoleh dari buku. Oleh karena itu, buku merupakan komponen wajib yang harus ada di lembaga pendidikan baik lembaga pendidikan formal maupun nonformal. Lembaga pendidikan merupakan tempat dilaksanakannya proses pembelajaran sebagai proses interaksi antara peserta didik dengan pendidikdan sumber belajar pada suatu lingkungan belajar.

Buku merupakan sumber belajar yang praktis mengingat penggunaannya yang fleksibel, pemeliharaan yang murah serta ketersediaannya yang mudah. Penggunaan buku tidak dibatasi waktu, tempat, maupun usia pengguna namun tetap ada ketentuan dalam penyusunan maupun penggunaannya. Hal tersebut menjadikan buku dapat digunakan sebagai sumber belajar yang tidak hanya digunakan di sekolah saja. Ada beberapa jenis buku yang dapat dipersiapkan dalam pengajaran. Salah satu dari jenis buku tersebut adalah buku teks.

Buku teks merupakan buku yang telah ditetapkan sebagai pegangan dalampembelajaran. Pengertian tersebut menunjukkan hendaknya buku teks sesuai dengan kurikulum pendidikan nasional dan berfungsi mendukung terbentuknya kompetensi lulusan siswa. Buku teks sebagai sumber belajar menjadi pegangan. Oleh karena itu, penyusunannya disesuaikan dengan tujuan pengajarannya.

Materiyang dimuat dalam buku teks hendaknya merupakan materi yang disusun saling berkaitan satu sama lain menjadi satu kesatuan dan tidak melenceng dari tujuan pengajaran. Buku teks mata pelajaran digunakan pada satuan pendidikan dasar dan menengah dipilih dari buku-buku teks pelajaran yang ditetapkan oleh menteri berdasarkan rekomendasi penilaian kelayakan dari Badan Standar Nasional Pendidikan (BSNP). Buku teks pelajaran untuk mata pelajaran muatan lokal yang digunakan pada satuan pendidikan dasar dan menengah dipilih dari buku-buku teks pelajaran yang ditetapkan oleh gubernur atau bupati atau jugawalikota sesuai dengankewenangan masing-masing berpedoman pada standar buku teks pelajaran yang ditetapkan oleh menteri.

Ibaratmakanan, penyusunan buku teks perlu diperhatikan kandunganisinya. Beberapa pihak telah melakukan beberapa penilaian terhadap buku-buku ajar yang meliputi empat aspek, yaitu: kelayakan isi, kelayakan penyajian, kelayakan kebahasaan, dan kelayakan kegrafikan. Ada beberapa buku ajar yang bermasalah di antaranya tidak memenuhi syarat dari segi isi. Baru-baru ini terdapat permasalahan mengenai materi dalam buku pelajaran yang dinilai kurang pantas. Buku ajar yang baik memiliki kriteria tertentu atau standar tertentu seperti tentang relevansinya dengan kurikulum yang sedang berlaku saat ini, kesesuaian metode dengan materi 


\section{JURNALILMIAH}

BINAEDUKASI

ISSN 1979-8598E-ISSN: 2655-8378

http://journal.binadarma.ac.id/index.php/jurnalbinaedukasi

Vol. 11, No. 2, Desember 2018, 109-123

yang disampaikan, isi buku atau sudut keilmuannya yaitu apakah teori-teori yang digunakan di dalam penulisan buku ajar ini sudah sesuai atau belum. Oleh karena itu, perlu diadakannya telaah terhadap buku teks tersebut, dalam hal ini BSE (Buku Sekolah Elektronik) apakah BSE tersebut telah benar-benar memenuhi kriteria buku teks yang baik sesuai dengan kriteria kualitas yang telah ditetapkan BSNP.

Selain materi yang disesuaikan dengan kurikulum pendidikan nasional, sebagai suatu sumber yang digunakan oleh siswa hendaknya buku teks mempunyai suatu bentuk atau cara penyajian yang menarik perhatian siswa untuk menggunakan serta mempelajarinya. Ibarat suatu produk yang dikemas dengan bungkus warna-warni untuk menarik konsumen, buku teks disajikan dengan tampilan luar yang berupa-rupa pula meski tetap mengikuti ketentuan yang berlaku. Pengibaratan seperti itu tidak sepenuhnya menunjukkan layout suatu buku teks bukanlah satu-satunya hal yang menjadi pertimbangan dalam penyusunan serta pemilihan buku teks. Layout suatu buku teks bukan semata-mata penampilan luar atau sampulnya saja sebab tata letak materi yang dimuat pun merupakan hal yang akan menambah ketertarikan pembaca atau bahkan mempermudah dalam memahami materi.

Materi yang berkualitas jika disajikan dengan bentuk yang tidak menarik dapat mengurangi minat pembaca untuk mempelajarinya. Oleh karena itu, tulisan ini akan membahas kualitas atau kelayakan buku teks Tematik Terpadu Kurikulum 2013 untuk SD kelas IV khususnya mengenai tema Indahnya Kebersamaan dengan subtema pertama, Keberagaman Budaya Bangsaku. Telaah buku teks dilakukan dengan melihat kelayakan isi, kelayakan bahasa, dan kelayakan penyajian.

\section{METODOLOGIPENELITIAN}

\subsection{MetodePenelitian}

Penelitian ini merupakan penelitian deskriptif. Pengumpulan data dilakukan dengan teknik studi pustaka. Data yang diperoleh kemudian dirangkum dan diinterpretasikan sehingga menghasilkan gambaran yang jelas, terarah dan menyeluruh dari masalah yang menjadi objek penelitian.

\subsection{Buku Teks}

Buku teks adalah buku yang disusun para ahli untuk menunjang proses pembelajaran yang berisi ilmu pengetahuan hasil analisis terhadap kurikulum dalam bentuk tertulis (Ni'mah, 2014). Buku teks adalah buku pelajaran dalam bidang studi tertentu, yang merupakan buku 


\section{JURNALILMIAH}

BINAEDUKASI

ISSN 1979-8598E-ISSN: 2655-8378

http://journal.binadarma.ac.id/index.php/jurnalbinaedukasi

Vol. 11, No. 2, Desember 2018, 109-123

standar, yang disusun oleh para pakar dalam bidang itu untuk maksud-maksud dan tujuan instruksional, yang dilengkapi dengan sarana-sarana pengajaran yang serasi dan mudah dipahami oleh para pemakainya di sekolah-sekolah dan perguruan tinggi sehingga dapat menunjang sesuatu program pengajaran (Tarigan dan Tarigan, 2009: 13). Berdasarkan pendapat tersebut, buku teks digunakan untuk mata pelajaran tertentu. Penggunaan buku teks tersebut didasarkan pada tujuan pembelajaran yang mengacu pada kurikulum. Selain menggunakan buku teks, pengajar dapat menggunakan sarana-sarana ataupun teknik yang sesuai dengan tujuan yang sudah dibuat sebelumnya. Penggunaan yang memadukan buku teks, teknik serta sarana lain ditujukan untuk mempermudah pemakai buku teks terutama peserta didik dalam memahami materi.

Peraturan Pemerintah No.32 Tahun 2013 pasal 1 ayat 23 yang menyatakan bahwa buku teks pelajaran adalah sumber pembelajaran utama untuk mencapai kompetensi dasar dan kompetensi inti. Sementara itu, yang dimaksud dengan kompetensi inti adalah tingkat kemampuan untuk mencapai standar kompetensi lulusan yang harus dimiliki seorang peserta didik pada setiap tingkat kelas atau program. Kompetensi dasar adalah kemampuan untuk mencapai kompetensi inti yang harus diperoleh peserta didik melalui pembelajaran. Jadi, buku teks adalah buku acuan wajib untuk digunakan di sekolah yang memuat materi pembelajaran dalam rangka peningkatan keimanan dan ketakwaan, budi pekerti dan kepribadian, kemampuan penguasaan ilmu pengetahuan dan teknologi, kepekaan dan kemampuan estetis, serta potensi fisik dan kesehatan yang disusun berdasarkan standar nasional pendidikan.

Pusat perbukuan (http://puskurbuk.net) menyatakan bahwa buku teks pelajaran adalah buku acuan wajib untuk digunakan di sekolah yang memuat materi pembelajaran dalam rangka peningkatan keimanan dan ketakwaan, budi pekerti dan kepribadian, kemampuan penguasaan ilmu pengetahuan dan teknologi, kepekaan dan kemampuan estetis, potensi fisik dan kesehatan yang disusun berdasarkan Standar Nasional Pendidikan. Berdasarkan hal tersebut, buku teks merupakan buku standar yang disusun oleh pakar dalam bidangnya dan digunakan sebagai penunjang program pembelajaran.

\subsubsection{Fungsi Buku Teks}

Nasution (dikutip Prastowo, 2011) mengemukakan lima fungsi buku teks, sebagai berikut.
a) Sebagai bahan referensi atau bahan rujukan oleh peserta didik.
b) Sebagai bahan evaluasi.
c) Sebagai alat bantu pendidik dalam melaksanakan kurikulum.
d) Sebagai salah satu penentu atau teknik pengajaran yang akan digunakan pendidik, dan
e) Sebagai sarana untuk peningkatan karier dan jabatan. 


\subsubsection{Jenis-jenis Buku}

Surahman (dikutip Prastowo, 2011) menyatakan bahwa secara umum buku dibedakan menjadi empat jenis, sebagai berikut.

a. Buku sumber, yaitu buku yang biasa dijadikan rujukan, referensi, dan sumber untuk kajian ilmu yang lengkap.

b. Buku bacaan, yaitu buku yang hanya berfungsi untuk bahan bacaan saja, misalnya cerita, legenda, novel, dan sebagainya.

c. Buku pegangan, yaitu buku yang bisa dijadikan pegangan guru atau pengajar dalam melaksanakan proses pengajaran.

d. Buku bahan ajar, yaitu buku yang disusun untuk proses pembelajaran dan berisi bahanbahan atau materi pelajaran yang akan diajarkan.

Kemudian secara khusus buku teks pelajaran dibedakan menjadi dua macam, yaitu buku teks utama dan buku teks pelengkap (Mohammad dikutip Prastowo, 2011). Buku teks utama berisi bahan-bahan pelajaran suatu bidang studi yang digunakan sebagai buku pokok bagi peserta didik dan pendidik. Sementara itu, buku teks pelengkap adalah buku yang sifatnya membantu atau merupakan tambahan bagi buku teks utama serta digunakan oleh pendidik dan peserta didik.

\subsection{Pendekatan Tematik}

Model pembelajaran tematik adalah model pembelajaran terpadu yang menggunakan pendekatan tematik dengan melibatkan beberapa mata pelajaran untuk memberikan pengalaman bermakna kepada siswa (Prastowo, 2013). Pembelajaran tematik adalah pembelajaran yang menggunakantemadalammengaitkanbeberapamatapelajaransehinggamemberikanpengalamanber maknakepadasiswa (Effendi dikutipWahyuni, 2017). Hal ini dikarenakan pembelajaran tematik akan membuat siswa memahami konsep-konsep yang mereka pelajari melalui pengalaman langsung dan menghubungkannya dengan konsep lain yang telah dipahaminya.

Dalam praktiknya pendekatan tematik ini bertolak dari suatu tema yang dipilih dan dikembangkan oleh guru bersama siswa dengan memperhatikan keterkaitannya dengan isi mata pelajaran. Tema adalah pokok pikiran atau gagasan pokok yang menjadi pokok pembicaraan. Tujuan dari adanya tema ini bukan hanya untuk menguasai konsep-konsep suatu mata pelajaran, tetapi juga keterkaitannya dengan konsep dari mata pelajaran lain.

Mamat S. B. (dikutip Prastowo, 2013) menyatakan bahwa ada sembilan prinsip yang mendasari pembelajaran tematik, yaitusebagai berikut.
a. Terintegrasi dengan lingkungan atau bersifat kontekstual
b. Memiliki tema sebagai alat pemersatu beberapa mata pelajaran atau bahan kajian
c. Menggunakan prinsip belajar sambil bermain dan menyenangkan 


\section{JURNALILMIAH}

BINAEDUKASI

ISSN 1979-8598E-ISSN: 2655-8378

http://journal.binadarma.ac.id/index.php/jurnalbinaedukasi

Vol. 11, No. 2, Desember 2018, 109-123

d. Pembelajaran memberikan pengalaman langsung yang bermakna bagi siswa

e. Menanamkan konsep dari berbagai mata pelajaran atau bahan kajian dalam suatu proses pembelajaran tertentu

f. Pemisahan atau pembedaan antara satu pelajaran dengan mata pelajaran yang lain sulit dilakukan

g. Pembelajaran dapat berkembang dengan kemampuan, kebutuhan, dan minat siswa

h. Pembelajaran bersifat fleksibel

i. Penggunaan variasi metode dalam pembelajaran.

Penerapan pembelajaran tematik di sekolah juga memberikan banyak manfaat. Trianto (dikutip Lestari, 2017) menjelaskan bahwa pembelajaran tematik memiliki beberapa manfaat, yaitu (a) siswa mudah memusatkan perhatian pada satu tema tertentu; (b) siswa dapat mempelajari pengetahuan dan mengembangkan berbagai kompetensi dasar antar mata pelajaran dalam tema yang sama; (c) pemahaman terhadap materi pelajaran lebih mendalam dan berkesan; (d) kompetensi dasar dapat dikembangkan secara lebih baik; (e) siswa dapat merasakan kebermaknaan karena materi disajikan secara jelas; (f) siswa lebih bergairah belajar; (g) guru dapat menghemat waktu.

\subsection{Karakteristik Bahan Ajar Tematik}

Pada dasarnya, bahan ajar tematik memiliki karakteristik yang hampir sama dengan bahan ajar pada umumnya. Hanya saja yang membedakan adalah bahan ajar tematik didesain sedemikian rupa untuk mendukung proses pembelajaran tematik. Bahan ajar tematik harus memunculkan karakteristik dasar pembelajaran tematik, yaitu menstimulasi agar siswa aktif, menciptakan suasana pembelajaran yang menyenangkan, menyuguhkan pengetahuan yang holistik, dan memberikan pengalaman langsung kepada siswa (Prastowo, 2013). Holistik artinya suatu peristiwa yang menjadi perhatian dalam pembelajaran tematik diamati dan dikaji dari beberapa bidang studi sekaligus. Bermakna dalam pembelajaran tematik berarti pengkajian suatu fenomena dari berbagai macam aspek yang nantinya akan memberikan dampak kebermaknaan dari materi yang dipelajari. Otentik dalam pembelajaran tematik memungkinkan peserta didik memahami secara langsung konsep dan prinsip yang ingin dipelajari (Majid dalam Pratama, 2017).

\subsection{Kaidah dalam Menyusun Buku Teks Pelajaran}

Prastowo (2011) mengatakan bahwa buku yang baik memiliki tiga ciri, yaitu menggunakan bahasa yang baik dan mudah dimengerti, penyajiannya menarik dan dilengkapi 


\section{JURNALILMIAH}

BINAEDUKASI

ISSN 1979-8598E-ISSN: 2655-8378

http://journal.binadarma.ac.id/index.php/jurnalbinaedukasi

Vol. 11, No. 2, Desember 2018, 109-123

dengan gambar beserta keterangan-keterangan yang lengkap, isi buku menggambarkan sesuatu yang sesuai dengan ide penulisnya, dan isi atau kandungannya disusun berdasarkan kurikulum atau tafsiran tentang kurikulum yang berlaku.

Sementara itu, Surahman (dikutip Prastowo, 2011) mengatakan ada empat kaidah umum yang perlu diperhatikan dalam penyusunan buku teks pelajaran. Pertama, buku tidak boleh mengganggu ketentraman sosial. Kedua, buku tidak boleh mengandung SARA. Ketiga, buku tidak boleh menjadi bahan pro-kontra antara beberapa etnis, golongan, ras, suku bangsa, budaya, ataupun agama. Keempat, buku harus bisa dipertanggungjawabkan kebenarannya.

Selain itu, buku teks pelajaran harus memenuhi standar-standar tertentu. Standar yang dimaksud di sini meliputi persyaratan, karakteristik, dan kompetensi minimum yang harus terkandung di dalam suatu buku pelajaran. Standar lain diantaranya, standar penilaian, strandar materi, standar penyajian, dan standar bahasa atau keterbacaan.

\subsection{Kualitas Buku Teks Pelajaran}

BNSP dan Puskurbuk (2013, http://bsnp-indonesia.orgdan http://puskurbuk.net) mengatakan bahwa kualitas buku teks dapat dilihat berdasarkan aspek isi/ materi, penyajian, grafika, serta aspek kebahasaan. Materi dalam buku teks buku teks itu isinya haruslah sesuai dengan tujuan pembelajaran yang berdasar pada kurikulum, lebih baik lagi jika materi tersebut terintegrasi dengan pelajaran lain namun tetap menghargai hal-hal yang tidak bertentangan seperti agama. Materi buku teks diharapkan dapat membuat siswa giat mempelajari kembali meskipun di luar proses belajar mengajar.

Selain aspek materi, cara menyajikan materi dalam suatu buku teks diharapkan sistematis dan dapat membuat siswa lebih memahami pengetahuan yang sesuai dengan umur siswa. Aspek penyajian materi berhubungan erat dengan aspek grafika. Materi dalam buku teks hendaknya diimbangi dengan ilustrasi yang menarik dan sesuai dengan materi sehingga membantu siswa dalam memahami dan berimajinasi tentang suatu pokok bahasan. Aspek kebahasaan tidak kalah penting, dalam menyajikan materi hendaknya menggunakan bahasa yang mudah dipahami namun jika memungkinkan, penggunaan kata-kata dalam penyajian materi tidak monoton dan dikembangkan sesuai jenjang atau tingkatan sekolah siswa.

Tarigan dan Tarigan (2009: 13) mengungkapkan bahwa ilmu pengetahuan dapat dihimpun ke dalam suatu wadah yang selalu tersedia secara permanen dengan pertolongan buku-buku. Buku teks memberi kesempatan pada pemiliknya untuk menyegarkan kembali ingatan.Bahkan pembacaan kembali dapat pula dipakai sebagai pemeriksaan daya ingat seseorang terhadap hal yang pernah dipelajarinya melalui buku teks. Sarana khusus yang ada dalam suatu buku teks dapat menolong para pembaca untuk memahami isi buku. Sarana seperti 


\section{JURNALILMIAH}

BINAEDUKASI

ISSN 1979-8598E-ISSN: 2655-8378

http://journal.binadarma.ac.id/index.php/jurnalbinaedukasi

Vol. 11, No. 2, Desember 2018, 109-123

skema, diagram, matriks, gambar-gambar ilustrasi, dan sebagainya, berguna sekali dalam mengantar pembaca ke arah pemahaman isi buku.

Dilihat dari segi kelayakan penyajian, penyusunan buku teks perlu mempertimbangkan teknik penyajian, pendukung penyajian, penyajian pembelajaran, dan koherensi serta keruntutan alur berpikir. Sementara itu, dari segi kegrafikaan yang harus diperhatikan adalah ukuran format buku, desain bagian kulit, desain bagian isi, kualitas kertas, kualitas cetakan, dan kualitas jilidan.

Buku teks yang berkualitas sudah semestinya memenuhi aspek-aspek tersebut. Keempat aspek yang dijelaskan di atas merupakan aspek yang sangat berhubungan sehingga sangat diharapkan penyusun buku teks dapat memenuhi salah satu aspek tanpa mengurangi kualitas aspek lainnya. Contohnya, ilustrasi yang digunakan dalam buku teks semestinya merupakan ilustrasi yang bagus dan menarik namun jangan sampai mengganggu materi yang disampaikan atau bahkan ilustrasinya bagus tetapi tidak sesuai dengan materi.

\section{HASIL DAN PEMBAHASAN}

\subsection{Hasil Analisis Mengenai Kualitas Buku Teks Tematik Terpadu Kurikulum 2013 untuk SD Kelas IV}

Berikut hasil telaah yang telah dilakukan terhadap buku teks Tematik Terpadu Kurikulum 2013 untuk SD kelas IV. Penyusunan buku ini sudah berdasarkan Kurikulum 2013 sehingga analisis kelayakan isi pun akan menggunakan Kurikulum 2013.

Salah satu pendekatan yang digunakan dalam kurikulum 2013 adalah pendekatan ilmiah atau scientific approach. Pendekatan ilmiah meliputi kegiatan mengamati, menanya, mencoba, menalar, dan mengomunikasikan. Pendekatan ini harus tercermin dalam buku teks.

Khusus untuk jenjang sekolah dasar, pemerintah memberlakukan sistem pembelajaran tematik. Model pembelajaran tematik adalah model pembelajaran terpadu yang menggunakan pendekatan tematik dengan melibatkan beberapa mata pelajaran untuk memberikan pengalaman bermakna kepada siswa (Prastowo, 2013). Hal ini dikarenakan pembelajaran tematik akan membuat siswa memahami konsep-konsep yang mereka pelajari melalui pengalaman langsung dan menghubungkannya dengan konsep lain yang telah dipahaminya.

BSNP (Badan Standar Nasional Pendidikan) menetapkan beberapa kriteria kualitas buku teks pelajaran bahasa Indonesia yang memenuhi syarat kelayakan, yang meliputi empat komponen yaitu sebagai berikut. 


\section{JURNALILMIAH}

BINAEDUKASI

ISSN 1979-8598E-ISSN: 2655-8378

http://journal.binadarma.ac.id/index.php/jurnalbinaedukasi

Vol. 11, No. 2, Desember 2018, 109-123

\section{A. Kelayakan Isi}

Kelayakan isi dalam menilai kriteria kualitas penulisan buku teks bahasa Indonesia meliputi beberapa komponen sebagai berikut.

\section{1) Kesesuaian Materi dengan Kompetensi Inti (KI) dan Kompetensi Dasar (KD)}

Buku teks tematik terpadu yang baik seharusnya berisi materi yang mendukung tercapainya KI (Kompetensi Inti) dan KD (Kompetensi Dasar) dari mata pelajaran yang tercakup dalam tema-tema tertentu tersebut. Materi yang disajikan mencakup semua materi yang terkandung dalam Kompetensi Inti (KI) dan Kompetensi Dasar (KD). Materi yang disajikan juga mencerminkan jabaran yang mendukung pencapaian semua Kompetensi Dasar (KD). Selanjutnya materi yang disajikan mulai dari pengenalan konsep, definisi, prosedur, tampilan output, contoh, kasus, latihan, sampai dengan interaksi antar-konsep sesuai dengan tingkat pendidikan peserta didik dan sesuai dengan yang diamanatkan oleh Kompetensi Dasar (KD). KI dan KD merupakan tolok ukur pedoman dalam pembelajaran dan merupakan tujuan ketercapaian pembelajaran.

Materi yang terdapat dalam buku teks ini sudah sesuai dengan KI dan KD. KI dan KD tidak dituliskan secara eksplisit (gamblang) di dalam buku teks, namun ditulis secara implisit. KI dan KD tiap mata pelajaran yang terangkum dalam tema dan subtema memang tidak dituliskan atau dinyatakan secara gamblang sehingga pemisahannya tampak tidak jelas. Namun, ini merupakan prinsip dari pembelajaran tematik itu sendiri, seperti yang telah dikemukakan di atas. Khusus untuk ketercapaian KI, guru diharapkan melakukan penguatan, pembiasaan, peneladaan, dan pembudayaan di sekolah

Selain itu, apabila dilihat dari segi kedalaman materi, buku teks ini tidak terlalu membahas materi secara mendalam. Buku ini lebih mengarahkan siswa agar mereka mendapatkan pengalaman langsung yang bermakna. Dengan demikian, diharapkan pembelajaran dapat berkembang sesuai dengan kemampuan, kebutuhan, dan minat siswa.Keluasan materi berkenaan dengan materi yang disajikan harus mencerminkan jabaran yang mendukung pencapaian semua Kompetensi Dasar (KD) dan sesuai dengan tingkat pendidikan peserta didik. Materi yang terdapat dalam buku teks ini juga sudah dipaparkan secara luas dan mendetail.

\section{2) Kesesuaian Materi dengan Kurikulum}

Buku teks bahasa Indonesia yang memenuhi syarat kriteria kelayakan berdasar BSNP haruslah sesuai dengan kurikulum yang berlaku (Kurikulum 2013). Kurikulum merupakan suatu usaha untuk menyampaikan asas-asas dan ciri-ciri yang penting dari suatu rencana pendidikan dalam bentuk yang sedemikian rupa sehingga dapat dilaksanakan oleh guru di sekolah. Selain itu, materinya juga sudah sesuai dengan KD. Misalnya, pada pembelajaran 1 materi yang disajikan adalah mengenai keberagaman suku bangsa, pakaian adat, dan makanan khas dari 


\section{JURNALILMIAH}

BINAEDUKASI

ISSN 1979-8598E-ISSN: 2655-8378

http://journal.binadarma.ac.id/index.php/jurnalbinaedukasi

Vol. 11, No. 2, Desember 2018, 109-123

daerah tertentu. Pembelajaran 1 ini terdiri atas mata pelajaran PPKn, bahasa Indonesia, dan SBdB. Sementara itu, pembelajaran 2 terdiri atas mata pelajaran bahasa Indonesia, dan Matematika. Meskipun demikian, pembagian tiap mata pelajaran yang terdapat dalam tema dan subtema tidak tampak secara jelas.

\section{3) Keakuratan Materi}

Keakuratan materi dalam kriteria kualitas buku teks menurut BSNP meliputi keakuratan wacana, diagram, gambar, contoh, konsep maupun teori. Materi yang disajikan dalam buku teks tematik terpadu ini harus sesuai dengan kenyataan, tidak dibuat-buat dan efisien untuk meningkatkan pemahaman peserta didik. Hal ini dapat terlihat dengan adanya sumber yang jelas dan sesuai dengan tingkat pemahaman siswa. Untuk keakuratan konsep dan teori tercermin dari kesesuaian teori dengan konsep yang disajikan dalam mencapai Kompetensi Dasar (KD). Selain itu keakuratan teori dan konsep itu terlihat juga dalam penggunaan yang tepat sesuai dengan fenomena yang dibahas dan tidak menimbulkan keambiguan. Materi teks yang digunakan dalam buku teks ini sudah mencantumkan sumber yang jelas, adanya kesesuaian teks yang dipilih dengan tingkat pemahaman siswa.

\section{4) Kemutakhiran Materi}

Materi dalam buku teks haruslah mutakhir, mengikuti kurikulum yang berlaku. Hal ini berarti materi ataupun contoh yang disajikan haruslah aktual. Gambar, diagram dan ilustrasi diutamakan yang aktual, namun juga dilengkapi penjelasan atau perbandingan dengan perangkat yang telah ada sebelumnya. Contoh dan kasus yang disajikan sesuai dengan situasi serta kondisi di Indonesia.

\section{5) Mendorong Keingintahuan}

Materi yang baik harus dapat menumbuhkan keingintahuan serta kreativitas siswa sehingga merangsang, memantapkan, menantang dan menggiatkan aktivitas siswa. Hal ini dapat terlihat dari pertanyaan-pertanyaan yang diajukan kepada siswa yang memancing kreativitas siswa dan menuntut kemampuan berpikir tingkat tinggi siswa. Selain itu, isi teks dapat menambah pengetahuan pembaca.

\section{6) Substansi Keilmuan dan Life Skill}

Substansi keilmuan dalam buku teks tematik terpadu ini mencakup mata pelajaran bahasa Indonesia, Matematika, PPKn, SBdB, PJOK, IPS, dan IPA. Ketujuh mata pelajaran tersebut sudah terintegrasi dalam materi buku teks. Sedangkan pemilihan materi, contoh, permasalahan dalam isi dapat meningkatkan kemampuan life skill dan kemampuan berpikir tingkat tinggi siswa sehingga dapat digunakan di dalam kehidupan bermasyarakat. Selain itu, buku ini pun sudah menyajikan materi kebahasaan secara terintegrasi. 


\section{7) Pengayaan}

Isi BTBI selain termuat dalam SK dan KD juga harus dapat memperkaya ilmu pengetahuan siswa baik dalam bidang akademik maupun nonakademik yang mendukung tercapainya tujuan pembelajaran.

\section{8) Keberagaman Nilai}

Kelayakan isi juga dilihat dari keberagaman nilai-nilai maupun norma-norma yang berlaku dalam masyarakat. Buku teks yang baik tidak memberikan uraian-uraian yang menjurus kepada penggoyahan nilai-nilai yang berlaku.

\section{B. Kelayakan Bahasa \\ 1) Lugas}

Bahasa yang digunakan dalam buku teks bahasa Indonesia adalah bahasa yang lugas (apa adanya), tidak berbelit-belit, hanya mencantumkan penjabaran materi yang pokok, penting, dan yang perlu saja. Selain itu, buku teks ini menggunakan kalimat yang mampu mewakili isi pesan dan informasi yang ingin disampaikan dengan tetap mengikuti tata kalimat bahasa Indonesia. Kalimat-kalimatnya pun sederhana dan langsung ke sasaran.

\section{2) Komunikatif}

Buku teks ini menggunakan bahasa yang komunikatif sehingga pembaca khususnya siswa dapat dengan mudah memahami dan mengerti isi buku. Teks mengenai Indahnya Kota Jam Gadang, Tari Kipas Pakarena, dan Mengenal Suku Minang disampaikan dengan bahasa yang menarik dan lazim dalam komunikasi tertulis bahasa Indonesia.

\section{3) Dialogis dan Interaktif}

Buku teks ini mengunakan bahasa yang dapat memotivasi siswa, bahasa yang digunakan membangkitkan rasa senang ketika peserta didik membacanya dan mendorong mereka untuk mempelajari buku tersebut secara tuntas. Selain itu, buku teks juga harus mendorong siswa untuk berpikir kritis, bahasa yang digunakan mampu merangsang peserta didik untuk mempertanyakan suatu hal lebih jauh, dan mencari jawabnya secara mandiri dari buku teks atau sumber informasi lain.

\section{4) Kesesuaian dengan Perkembangan Peserta Didik}

Buku teks ini sudah sesuai dengan tingkat perkembangan intelektual peserta didik. Bahasa yang digunakan dalam menjelaskan suatu konsep sudah sesuai dengan tingkat perkembangan kognitif peserta didik. Kesesuaian dengan tingkat perkembangan emosional peserta didik juga merupakan hal yang perlu diperhatikan dalam buku teks, bahasa yang digunakan sesuai dengan tingkat kematangan emosional peserta didik. 


\section{JURNALILMIAH}

BINAEDUKASI

ISSN 1979-8598E-ISSN: 2655-8378

http://journal.binadarma.ac.id/index.php/jurnalbinaedukasi

Vol. 11, No. 2, Desember 2018, 109-123

\section{5) Kesesuaian dengan Kaidah Bahasa Indonesia}

Dalam penulisan Buku teks terutama subtema Keberagaman Budaya Bangsaku sudah memperhatikan kaidah bahasa Indonesia baik dan benar, sesuai dengan pedoman umum ejaan bahasa Indonesia (PUEBI), dan Kamus Besar Bahasa Indonesia (KBBI).

\section{6) Penggunaan Istilah, Simbol, dan Ikon}

Dalam buku teks Tematik Terpadu kelas IV ini terdapat istilah permainan tradisional seperti permainan Benteng dan Gobak Sodor. Penggunaan istilah ini perlu diperjelas dengan mencari padanannya dalam bahasa yang berbeda. Sebab tidak semua daerah mengerti dengan penggunaan bahasa ini bahkan mungkin daerah lain mengenalnya dengan istilah yang berbeda. Dalam buku teks ini penggunaan istilah dan penggambaran simbol atau ikon yang menggambarkan suatu konsep harus konsisten antar-bagian dalam buku konsisten. Buku teks ini menggunakan angka dan huruf secara konsisten, misalnya (1) atau (a).

\section{Kelayakan Penyajian \\ 1) Teknik Penyajian}

Teknik penyajian merupakan faktor penentu kualitas suatu buku teks. Teknik penyajian dalam buku teks tematik terpadu ini sudah baik. Ini dapat dilihat dari adanya kekonsistenan sistematika penyajiannya, yaitu adanya bagian pendahuluan, isi, dan penutup. Bagian pendahuluan pada buku teks ini adalah pengantar awal materi yang akan dipelajari siswa. Penulis juga memaparkan tujuan yang hendak dicapai dari pembelajaran ini.

Keruntutan konsep dalam penyajian buku teks berhubungan dengan penyajian konsep disajikan secara runtun mulai dari yang mudah ke sukar, dari yang konkret ke abstrak dan dari yang sederhana ke kompleks, dari yang dikenal sampai yang belum dikenal. Materi bagian sebelumnya bisa membantu pemahaman materi pada bagian selanjutnya.

\section{2) Pendukung Penyajian}

Pendukung penyajian dari buku teks berhubungan dengan penyajian yang dapat memotivasi pembaca khususnya siswa dalam membaca suatu buku teks. Pendukung penyajian dapat dilihat dari adanya uraian mengenai apa yang akan dicapai peserta didik setelah mempelajari bab tersebut dalam upaya membangkitkan motivasi belajar. Dengan adanya ini maka siswa akan termotivasi dalam mempelajari tiap bagian.

Selain itu, buku ini memberikan contoh soal dan penjelasan yang mudah dimengerti. Contoh-contoh soal dalam buku teks ini berfungsi untuk membantu menguatkan pemahaman konsep yang ada dalam materi bagi pembaca khususnya siswa. Selain itu, contoh-sontoh soal dan latihan yang diberikan akan melatih siswa dalam berpikir kritis dan kreatif.

Buku ini juga dilengkapi latihan-latihan setelah contoh soal dan pembahasan. Latihanlatihan ini sudah dilengkapi instruksi pengerjaan untuk siswa. Latihan-latihan yang diberikan 


\section{JURNALILMIAH}

BINAEDUKASI

ISSN 1979-8598E-ISSN: 2655-8378

http://journal.binadarma.ac.id/index.php/jurnalbinaedukasi

Vol. 11, No. 2, Desember 2018, 109-123

terintegrasi dalam materi atau dengan kata lain buku ini tidak memiliki latihan pada setiap akhir bab. Hal ini dimaksudkan agar siswa dapat langsung mengetes pemahaman mereka terhadap materi yang baru saja dipelajari. Selain itu, buku ini juga menyajikan evaluasi di akhir pembahasan tiap subtema. Ini akan membantu guru dalam mengevaluasi kinerja siswa setelah menyelesaikan subtema Keberagaman Budaya Bangsaku.

Apabila dilihat dari sisi pengantar buku, buku ini sudah berisi tujuan penulisan buku teks pelajaran bahasa Indonesia, sistematika buku, materi apa saja yang harus diberikan ke peserta didik untuk satuan masa pengajaran atau satu semester tertentu, cara belajar yang harus diikuti, serta hal-hal lain yang dianggap penting bagi peserta didik, yang ditulis pada awal buku teks. Sementara itu, petunjuk mengajar bagi guru dan lembaran penilaian disajikan dalam buku terpisah

Sayangnya, dalam buku ini tidak terdapat glosarium, daftar indeks, daftar tabel, daftar gambar, dan lampiran. Buku ini hanya mencantumkan daftar pustaka di bagian akhir buku. Glosarium yakni kamus kosakata atau glosari yang disediakan di bagian akhir buku teks untuk memudahkan pencarian kata yang mungkin belum diketahui artinya oleh pembaca. Glosarium sangat penting bagi pembaca (siswa), karena dapat membantu siswa bila menemukan kata-kata yang asing, serta memperkaya pengetahuan siswa akan kosa kata.

Sementara itu, daftar indeks adalah daftar kata penting atau indeks dari kata-kata yang dimuat dan digunakan dalam buku teks yang dibuat dan dilengkapi dengan nomor halaman. Indeks disusun secara alfabetis dan terletak pada bagian akhir buku. Daftar indeks membantu pembaca dalam mencari informasi dari istilah yang terdapat dalam indeks dengan membuka halaman yang tertera di belakang istilah.Kehadiran daftar pustaka dalam setiap buku teks atau buku pelajaran sangat penting. Daftar pustaka ini untuk menunjukkan sumber-sumber rujukkan dari materi-materi yang ada dalam buku teks tersebut. Daftar pustaka disusun dengan format nama pengarang (disusun terbalik), tahun terbit buku, judul buku (dicetak miring), kota terbit, dan nama penerbit, nama serta lokasi situs internet serta tanggal akses situs (jika memakai acuan yang memiliki situs).

Lampiran pada buku teks biasanya memuat beberapa daftar sumber bahan yang ada dalam buku yang dibutuhkan dalam memahami materi yang disajikan dalam buku teks. Lampiran ini bersifat tambahan, biasanya Lampiran memuat informasi atau bahan pendukung, antara lain data dan program yang diujicobakan dalam buku dan bahan latihan lanjut. Lampiran bisa disimpan dalam CD atau dapat diakses secara daring.

\section{3) Penyajian Pembelajaran}

Penyajian dalam sebuah buku teks tematik terpadu harus bersifat interaktif dan partisipatif, yaitu ada bagian yang mengajak pembaca untuk berpartisipasi, misalnya dengan mengajak siswa bernyanyi. Penyajian dalam sebuah buku teks juga berkaitan dengan metode 


\section{JURNALILMIAH}

BINAEDUKASI

ISSN 1979-8598E-ISSN: 2655-8378

http://journal.binadarma.ac.id/index.php/jurnalbinaedukasi

Vol. 11, No. 2, Desember 2018, 109-123

dan pendekatan penyajian yang biasanya diarahkan ke metode ilmiah atau scientific approach, dan materi dan latihan diberikan secara terintegrasi (tidak dipisahkan).

\section{SIMPULAN}

Berdasarkan analisis yang telah dilakukan terhadap buku teks Tematik Terpadu SD kelas IV dapat disimpulkan bahwa kualitas buku teks sudah baik. Analisis dilakukan berdasarkan tiga segi kelayakan, yaitu kelayakan isi, kelayakan bahasa, dan kelayakan penyajian.

Dilihat dari kelayakan isi, buku ini sudah menyajikan materi sesuai dengan kurikulum terutama KI dan KD. Meskipun KI dan KD tidak dituliskan secara eksplisit (gamblang) di dalam buku teks, namun ditulis secara implisit.

Dilihat dari kelayakan bahasa, buku ini sudah menggunakan bahasa lugas, komunikatif, bersifat interaktif, dan sesuai dengan kaidah bahasa Indonesia yang baik dan benar.

Dilihat dari kelayakan penyajian, buku ini memiliki keruntutan konsep dalam penyajian BTBI berhubungan dengan penyajian konsep disajikan secara runtun mulai dari yang mudah ke sukar, dari yang konkret ke abstrak dan dari yang sederhana ke kompleks, dari yang dikenal sampai yang belum dikenal. Materi bagian sebelumnya bisa membantu pemahaman materi pada bagian selanjutnya. Buku ini juga dilengkapi dengan daftar tabel, daftar gambar, glosarium, indeks, daftar pustaka, dan lampiran.

\section{DAFTAR PUSTAKA}

BNSP. (2014). "Instrumen Penilaian Buku Teks Pelajaran".http://bsnp-indonesia.org diunduh pada tanggal 22 Maret 2018.

Kelembagaan Ristekdikti. (2013). "Peraturan Pemerintah Republik Indonesia Nomor 32 Tahun 2013 Tentang Perubahan Atas Peraturan Pemerintah Nomor 19 Tahun 2005 Tentang Standar Nasional Pendidikan”. Diunduh dari http://kelembagaan.ristekdikti.go.id/wpcontent/uploads/2016/08/PP0322013.pdf pada 22 Februari 2019.

Lestari, WestriSetyo, dkk. (2017). "Pengembangan Bahan Ajar Tematik untuk Siswa Kelas IV". Jurnal Pendidikan: Teori, Penelitian, dan Pengembangan, Volume 2(11): 1469-1474.

Ni'mah, Z. (2014). "Buku Teks dan Komponen Penilaian Buku Teks Kurikulum 2013". Diunduh dari http://eprints.walisongo.ac.id/4196/3/103511028_bab2.pdfpada 22 Maret $\underline{2018}$.

Prastowo, A. (2011). Panduan Kreatif Membuat Bahan Ajar Inovatif. Yogyakarta: Diva Press. 


\section{JURNALILMIAH}

BINAEDUKASI

ISSN 1979-8598E-ISSN: 2655-8378

http://journal.binadarma.ac.id/index.php/jurnalbinaedukasi

Vol. 11, No. 2, Desember 2018, 109-123

(2013). Pengembangan Bahan Ajar Tematik. Yogyakarta: Diva Press.

Pratama, Mukhlis. (2017). "Pembelajaran Tematik". Diunduh dari http://eprints.umm.ac.id/35540/3/jiptummpp-gdl-mukhlispra-48156-3-12.bab-i.pdf pada 22 Maret 2018.

Puskurbuk. (2013). "Buku Teks Pelajaran”. http://puskurbuk.net/web/lainlain/bukutekspelajaran.html diunduh pada 12 Desember 2013.

Tarigan, H.G dan Tarigan, D. (2009). Telaah Buku Teks Bahasa Indonesia. Bandung: Angkasa.

Wahyuni, Hermin Tri, dkk. (2017). "Implementasi Pembelajaran Tematik Kelas 1 SD". Diunduh dari http://journal2.um.ac.id/index.php/edcomtech/article/viewFile/1799/1039 pada 20 Mei 2018. 